Ks. Artur Stępień SAC

\title{
OSOBA FORMATORA W PROCESIE INTERIORYZACJI WARTOŚCI Z UWZGLĘDNIENIEM ASPEKTÓW DYNAMIKI OBECNOŚCI I NIEOBECNOŚCI
}

Formator in the process of interiorization of the values, taking into account the dynamics of presence and absence

\section{Wstęp}

Odnosząc się do kwestii formacji i jej roli w procesie interioryzacji, który jest jedynym dojrzałym sposobem przeżywania wartości, dochodzimy do pytania: co jest dla tego procesu najważniejsze. Luigi Rulla w swej książce Antropologia powołania chrześcijańskiego mówi, że „w ostatecznej analizie transcendentną wartością jest osoba - Chrystus. Dlatego jesteśmy wezwani do transcendencji według nowego przykazania miłości: kochać tak jak kocha Chrystus"1. Idąc za tą myślą, znajdującą swe źródło w Ewangelii wg św. Jana (J 13, 34-35), odkrywamy, że to miłość jest jakością charakteryzującą chrześcijan. Naturalnie istnieje cały wachlarz wartości przekazanych nam przez Pana, skondensowanych chociażby w Kazaniu na Górze, ale posiadają one swą wagę poprzez zakurzenie się w Jego miłości. Czasem wydaje się, że w formacji to podejście jest traktowane $\mathrm{z}$ dystansem, sprawia bowiem wrażenie mało konkretnego, trudnego do weryfikacji.

Jeśli przyjmiemy za punkt wyjścia przekonanie, że najwyższą wartością dla chrześcijanina jest osoba - Jezus Chrystus, to w konsekwencji wyznacza nam to bardzo konkretny szlak wzrostu i dojrzewania do pełni wiary, objawiającej się w uczynkach (por. Jk 2, 14-19). Proces wzrostu, autotranscendencji, życia w wolności jest relacją

1 L. Rulla, Antropologia della vocazione cristiana I, Bologna 2006, s. 228. 
z „Ty”, który całkowicie nas przekracza i jednocześnie jest bliżej nas niż my sami. To relacja staje się kontekstem prawdziwego ludzkiego i duchowego wzrostu. Takie otwarcie na głęboką i intymną przyjaźń z Jezusem wymaga i zakłada otwartość i zdolność do intymnej relacji z sobą i z braćmi. Argument ten odzwierciedla punkt styczny pomiędzy umiejętnościami i uwarunkowaniami natury psychologicznej i duchowej.

Stąd wynika waga dojrzałości zarówno samego formowanego, jak i formatora, albowiem ten drugi staje się w konkretnej sytuacji świadkiem dynamiki wewnętrznej osoby prowadzonej, a ta już może być uchwytna. Ta kwestia była już podejmowana wiele razy w różnych publikacjach o tematyce powołaniowej. Proponowane spojrzenie skupia się przede wszystkim na roli formatora, który swoimi naturalnymi i nabytymi umiejętnościami może znacząco wpłynąć na kształtowanie się w młodym człowieku pragnienia pozostawania w drodze ku pełni wolności w ekspresji wspomnianej wartości nadrzędnej, czyli miłości Chrystusa. Od wielu lat zajmujemy się kwestią jakości przygotowania dobrych formatorów, którzy będą odpowiedni w obecnej sytuacji Kościoła i całego społeczeństwa. Formator na dziś jest zdolny służyć drugiemu w taki sposób, aby razem stawali się bardziej ludzcy. Jesteśmy jednak świadomi, że zarówno formowani, jak i formatorzy są dziećmi dzisiejszego świata, oraz że jedni i drudzy są spadkobiercami zarówno mocnych, jak i słabych stron społeczeństwa.

Dokumentu Kongregacji Wychowania Katolickiego Wytyczne do przygotowania wychowawców w seminariach (1993 r.) w rozdziale III zawiera wykaz kryteriów stosowanych przy wyborze formatorów i stwierdza, że Kościół w tym aspekcie jest bardzo wymagający oraz że wychowawcy, „przełożeni i profesorowie seminarium muszą być wybierani z najlepszych"2. Wytyczne te proponują od początku rozróżnienie cech formatora w dwóch płaszczyznach, a mianowicie na cechy wrodzone i nabyte.

2 Sobór Watykański II, Optatam totius. Dekret o formacji kapłańskiej, Rzym 1965 , nr 5 . 
„Powołanie formatora zakłada z jednej strony pewien „charyzmat”, który wyraża się w naturalnych darach i łasce, a z drugiej umiejętnościach i postawach, które trzeba nabyć. W każdej wypowiedzi na temat osobowości formatora zawsze będzie obecny ten podwójny aspekt: każda $\mathrm{z}$ cech pożądanych $\mathrm{u}$ wychowawcy $\mathrm{w}$ seminarium zawiera elementy niejako wrodzone, jak i te, które powinny być stopniowo nabywane poprzez studium i doświadczenie" .

Następnie dokument Kongregacji dokonuje prezentacji kryteriów, które wydają się oczywiste. Oto one: duch wiary, poczucie duszpasterskie, ludzka dojrzałość i równowaga psychiczna, jasna i dojrzała zdolność do miłości, umiejętność dialogu i słuchania, umiejętność komunikacji, pozytywne uwagi i krytyka współczesnej kultury ${ }^{4}$. Po zapoznaniu się z katalogiem cech oczekiwanych od formatora oraz chcąc uwolnić się od błędu idealizowania rzeczywistości, a przez to oderwania od niej, zaprezentuję zdecydowane przekonanie, że w rzeczywistości w naszych domach formacyjnych potrzebujemy nie doskonałych, ale „wystarczająco dobrych” formatorów.

\section{Wystarczająco dobry formator}

Za punkt wyjścia w tej kwestii przyjmijmy perspektywę zgodną z aktualną myślą o procesach rozwoju człowieka. Pierwszą rzeczą jest koncepcja formatora wystarczająco dobrego. Czasami wydaje się, że zbyt wiele mówimy o ideałach, które w danej sytuacji mogą pozostać nie osiągalne lub spoglądamy na kwestię formacji, podkreślając przede wszystkim problemy i trudności. Dlatego należy powiedzieć, że nie oczekuje się idealnych formatorów, jak i nie oczekuje się doskonałych ludzi. Formator nie musi być idealny, aby być w stanie odpowiednio wychowywać tych, którzy są mu powierzeni. To przekonanie może w pewnych kręgach budzić poczucie niepewności, a w innych ulgi.

Brytyjski psycholog i pediatra Donald Winnicott (1896-1971), zajmując się problemem rozwoju dzieci, poświecił się analizie znaczenia

3 Kongregacja Wychowania Katolickiego, Direttive sulla preparazione degli educatori nei seminari, Rzym 1993, nr 25.

4 Tamże, nr 26-42. 
głębokich i bezpiecznych relacji dla rozwoju osobowości. Jedną z nich, najbardziej istotną dla dziecka, jest relacja z matką. Winnicott mówi o matce, używając pojęcia „matki wystarczająco dobrej”. Aby stworzyć optymalne warunki do rozwoju osoby, formator powinien być wystarczająco dobry dla tego, który jest formowany. Jak to zrozumieć? Możemy sobie wyobrazić, dziecko, które rodzi się całkowicie zależne od rodziców i od początku doświadcza wielu potrzeb, wśród których jedna jest centralną, a mianowicie potrzeba karmienia, bycia karmionym. Matka aktywnie i z wrażliwością rozpoznaje te potrzeby. Matka wystarczająco dobra, a nie „super” dobra, rozpoznaje i odpowiada na potrzeby dziecka, ale bez antycypowania ich zaspokajania, aby dziecko mogło poczuć brak, i nie opóźniając się zanadto, by ten brak nie zamienił się w poczucie straty. Matka jest niedoskonała, ale zdrowa i emocjonalnie obecna. Jest spontaniczna, autentyczna, prawdziwa i ze swoimi lękami i obawami, zmęczeniem i zniechęceniem oraz poczuciem winy jest zdolna do dania poczucia bezpieczeństwa i miłości. Widzimy tu ważną dynamikę zachodzącą między obecnością i nieobecnością.

Przenosząc to na pole formacji, mamy nurt mówiący, że formator/formatorka powinien/a być wystarczająco dobry/a, to znaczy powinien/a być gotowy/a i zdolny/a do formowania w sytuacjach „obecności”, ale również pozostawić miejsce dla doświadczenia braku, który nie przekształca się w poczucie straty. Tutaj znowu widzimy dynamikę między obecnością i nieobecnością, w sensie, satysfakcji i frustracji. Elementy te powinny być obecne $\mathrm{w}$ formacji, aby kandydat miał szansę czuć się bezpiecznie, ale jednocześnie był zmobilizowany do poszukiwania odpowiedzi na pytania, które nosi w sobie. Jest jeszcze jeden element, o którym warto wspomnieć. Jest to realne zagrożenie, które może się pojawić podczas budowania relacji formacyjnej. Tym niebezpieczeństwem nie jest obecność lub nieobecność formatora, ale raczej brak świadomości własnych uczuć i własnych ograniczeń. Świadomość taka daje nam więcej miejsca

${ }^{5}$ Daniel Goleman ukazuje tę zależność na poziomie empatii, jednej z podstawowych dyspozycji oczekiwanej od formatora. Pisze on, że empatia bazuje na 
na wolność, która wchodzi w grę, gdy spotykają się ludzie niosący swoje jarzmo. Świadomość własnych ograniczeń, własnych potrzeb egocentrycznych, staje się miejscem, gdzie formator jest w stanie odróżnić „dobro samo w sobie” od „dobra dla mnie”. Innymi słowy, formator nie może korzystać z pozycji lub odpowiedzialności mu powierzonej dla spełniania swoich potrzeb. Jeśli te potrzeby nie są rozpoznane i uznane, zagrożenie „karmienia” ich swoimi decyzjami rośnie. W tej sytuacji, potrzeba posiadania obok osoby bliskiej i przyjaznej może zyskać centralne miejsce w procesie budowania relacji $\mathrm{z}$ formowanymi. W ten sposób cała formacja staje się zorientowana nie tyle na służbę innym, ile na wypełnianie swych wewnętrznych braków i deficytów. Tak dzieje się, gdy dochodzi do przekształcenia, często podświadomie, relacji duchowego towarzyszenia w relację przyjaźni. Inicjatywa takiej zmiany może również pochodzić od osoby formowanej, czego doświadczony formator powinien być świadomy. Inny przykład może dotyczyć formatora, który prezentuje silne oddziaływanie poprzez dyscyplinę i mocne wymagania. W sytuacji braku relacji otwartych wszystko kręci się wokół poczucia strachu i stresu. Może się tak zdażyć, że taki formator defensywny wykorzystuje podobny sposób zachowania w sposób podświadomy, dlatego że boi się bliskości i prezentuje wysoki poziom potrzeby agresji. Nie jest czymś właściwym to, aby ten, który postawiony jest w służbie drugiemu, gratyfikował swe egocentryczne braki. Prędzej czy później stanie się niezadowolony i sfrustrowany.

\section{Formator jako zraniony uzdrowiciel}

Wracając do koncepcji formatora „wystarczająco dobrego”, możemy zintegrować obie wizje. Nie oczekujemy formatorów idealnych, bez skazy, ale tych, którzy są świadomi swoich ran, i dzięki łasce Boga są w stanie służyć właśnie nimi. W ten sposób swą myśl prezentuje

samoświadomości. Im bardziej otwarci jesteśmy na własne emocje i odczucie (energie motywujące), tym bardziej zdolni będziemy do rozpoznawania i rozumienia świata wewnętrznego innych osób, a przede wszystkim tych, komu mamy towarzyszyć w drodze. Por. D. Goleman, Inteligenza emotiva, Milano 1999, s. 124. 
także Henri J.M. Nouwen, nadajac tytuł swej książce o kierownictwie duchowym: Zraniony uzdrowiciel ${ }^{6}$.

Dzisiejsze społeczeństwo, zbudowane w większości z osób „sparaliżowanych" duchowo, mówi Nouwen, ma ogromną potrzebę bycia przyjętym i zaakceptowanym. Towarzyszyć komuś, oznacza zrozumieć go, a zrozumieć, oznacza dzielić z nim los - drogę. Nouwen daje kilka zasad chrześcijańskiego towarzyszenia: osobiste zainteresowanie (otworzyć się na własne doświadczenia bólu i radości, jako źródła empatii), wiara w wartość i sens życia (pozwala odkryć ukryte znaczenie), nadzieja (motywacja na przyszłość, zakotwiczona w objawieniu się Boga w historii). Towarzyszyć zatem oznacza wejść w doświadczenie ludzkie wraz z osobą prowadzoną. W rzeczywistości, paradoks chrześcijańskiego towarzyszenia w wyjściu z więzienia lęku, oznacza wejście tam, ale razem, wraz z prowadzącym, w komunii bólu, który prowadzi do wolności. Posługa towarzyszenia zachodzi poprzez oddawanie swojego życia, czyli poprzez męczeństwo, które bierze początek z gotowości płaczu z tymi, którzy płaczą i śmiechu z tymi, którzy się śmieją, aby w ten sposób osobiste rany znajdowały balsam. Oczywiście, aby zrobić miejsce osobie prowadzonej, aby odważyła się otworzyć rany i zdjąć „stare bandaże”, formator musi mieć możliwość usunięcia się bez pozostawiania wrażenie oderwania. W przeciwnym razie może to stworzyć jeszcze więcej bólu i samotności, która sprawia nasilenie się lęku. Ta zdolność wymaga, aby przewodnik najpierw sam dał opatrzyć swoje rany. On, jako zraniony uzdrowiciel, jest powołany, by leczyć swoje rany i w tym być gotowym do pomocy innym.

Te rany stają się więc głównym źródłem mocy uzdrawiania, na wzór Jezusa Chrystusa. Kiedy nie boję się dotrzeć do mojej głębi, dochodzę do zrozumienia, że życie jest po to, aby kochać i być kochanym. Kochać miłością Pana. Kocham, bo zostałem poczęty przez miłość. Daje się, ponieważ moje życie jest darem. Uwalniać i leczyć, ponieważ sami zostaliśmy uwolnieni i uleczeni przez Pana, który ma serce większe niż nasze.

6 H.J.M. Nouwen, Il guaritore ferito, Brescia 2007. 
W Ewangelii wg św. Jana znajdujemy opis drogi uczniów idących do Emaus, która jest pewnym kompendium relacji formacyjnej, ukazującej pedagogię samego Jezusa. Po etapie zadzierzgnięcia bliskości wyrażonej w „opowiedzeniu siebie” przez uczniów, Jezus, pomimo przyłączenia się do uczniów jako anonimowy wędrowiec, nie rezygnuje z godności Pana i Boga. To On pozostaje gospodarzem, w odpowiednim czasie karmiącym do sytości. To On pozostaje Panem życia i historii, uzdrowicielem podnoszącym i dającym siłę. Niektórzy egzegeci wskazują, że uczniowie rozpoznali Jezusa po przebitych dłoniach, które pierwszy raz dostrzegli, kiedy łamał i dawał im chleb. Przejmujący jest ten obraz przebitych, zranionych dłoni, które karmią, które dają wsparcie i wzmocnienie. Sam Jezus dał wzór służby każdemu z nas. Dziś, kiedy człowiek potrzebuje drugiego człowieka, misja towarzyszenia w drodze może dokonywać się jedynie w świadomości własnych zranień. W przeciwnym razie stajemy się karykaturą, łamiąc chleb dłońmi w „białych rękawiczkach”. Jak przekazuje św. Łukasz, uczniowie rozpoznali Go po łamaniu chleba. Wiemy, że Jezus uczynił to zranionymi dłońmi. Jest to wskazówka dla każdego z nas, szczególnie dla tych, którzy boją się swych ran i chowająje w długich rękawach. W świadomości tych ran jest ukryta wiarygodna służba ${ }^{7}$.

Kiedy odkryjemy własne zakotwiczenia w naszym sercu, będziemy wolni, aby pozwolić innym wejść w przestrzeń stworzoną dla nich. Tak więc nasza obecność nie jest już groźna i wymagająca, ale przyjazna i wyzwalająca. Nasze rany i ograniczenia nie znikają, ale stają się narzędziem bliskości z drugim.

Jak pisze Nouwen, posługujący, który pogodził się ze swoją samotnością i czuje się u siebie „jak w domu”, będzie gościem gotowym zaoferować gościnę innym. To leczy, ponieważ nie zabiera cierpienia innym, ale zaprasza ich do uznania go. Towarzyszący nie jest lekarzem starającym się zlikwidować ból. On raczej przenika ból do poziomu, w którym może on być zakomunikowany i przestrzega, by człowiek nie cierpiał z niewłaściwych powodów, np. błędne założenia. Żaden

7 Por. F. Mickiewicz, Nowy Komentarz Biblijny. Nowy Testament. Ewangelia wg. św. Łukasza, III/2, Częstochowa 2012, s. 583-604. 
formator nie może zbawić nikogo. Może on tylko zaoferować siebie jako przewodnika. Tak więc w czasie prowadzenia, formowania, cierpienia, znaki desperacji przekształcane są w znaki nadziei.

Czy nie jest to sytuacja, aby powiedzieć: lekarzu, ulecz sam siebie? Być towarzyszącym w dzisiejszym społeczeństwie ludzi zranionych zakłada najpierw rozpoznanie własnego bólu i nadziei oraz odwagi zjednoczenia się z cierpieniem Jezusa Chrystusa. W ten sposób rany stają się źródłem uzdrowienia poprzez przestrzeń, w której doświadczenia osoby towarzyszącej i prowadzonej spotykają się.

W jaki sposób promować tę głęboką relację z Jezusem Chrystusem podczas okresu formacji? Formator, oferując swoją osobę, może obudzić pragnienie młodego człowieka do poszukiwania Jezusa bliskiego i konkretnego. Ta relacja między formatorem i formowanym odbywa się w przestrzeni pomiędzy jego obecnością, rozumianą jako postawa bliskości i zaspokojenia potrzeb oraz nieobecnością, czyli braku który przynosi frustrację, zwaną optymalną. Zarówno jeden jak i drugi aspekt powinien być obecny, aby kandydat wzrastał w dawaniu odpowiedzi coraz bardziej wymagających i dotykających struktury osoby.

Najpierw zobaczymy ważność dynamiki obecność-nieobecność a potem już bardziej szczegółowo zajmiemy się każdym z tych elementów. Nasza uwaga będzie skierowana przede wszystkim na zagadnienie empatii.

\section{Formator odpowiednio obecny i nieobecny}

Pozostajemy w kontekście relacji, mówiąc o przeżywaniu wartości. Jak widzieliśmy wcześniej, zdolność wchodzenia w relacje jest bardzo złożona i kształtuje się już od początku życia człowieka, już w łonie matki, gdy rozpoczyna się więź bardzo prymitywna, ale uzbrojona w ogromny potencjał. Teraz chcemy zastanowić się nad tym, jak możemy poprawić relacje interpersonalne dzięki działaniu formacyjnemu. Myślimy, przede wszystkim o okresie formacji początkowej, która powinna uwzględniać osobiste trudności kandydatów, które mogą mieć wpływ również na sposób przeżywania wartości chrześcijańskich, czyli krótko mówiąc, relacji z Jezusem Chrystusem. W tej 
dziedzinie wesprę się myślą Franco Imoda. Autor, mówiąc o formacji w perspektywie pedagogicznej, używa określenia „ponownego wzrostu" i „ponownej nauki” (ricrescita i re-imparare) ${ }^{8}$. W ten sposób kieruje naszą uwagę na jakość relacji między formowanymi w swym gronie oraz między nimi a formatorem, opierając wszystko na przekonaniu, że to właśnie relacje, które osoba buduje, mają ogromny potencjał wypełnienia braków i niedoskonałości przeszłości. Oczywistym jest, że relacje, które istnieją między dzieckiem a środowiskiem reprezentowanym przez matkę, w istotny sposób przyczyniają się pozytywnie lub negatywnie do uformowania osobistego „Ja", co $\mathrm{w}$ swoim czasie będzie kluczowym warunkiem w dalszym rozwoju, aby móc wejść $\mathrm{w}$ dojrzałe związki $\mathrm{z}$ innymi, w tym z Bogiem. Bloki i konflikty, które występują podczas rozwoju i często komplikują relacje, nie są ostatnim słowem, nie są niedonaprawienia. Właśnie to jawi się jako podstawa osobistego towarzyszenia, które ma na celu przywrócenie, „ponowne uczenie” $\mathrm{i}$,ponowny wzrost” $\mathrm{w}$ toku spotkania. W przypadku rozwoju naznaczonego trudnościami osoba potrzebuje cierpliwego odzyskania swej równowagi, często trwającego dość długo, który dokonuje się przez nowy typ relacji. Zwłaszcza emocjonalna bliskość jest w stanie odbudować tę równowagę, która nie mogła być prawidłowo uformowana. Jest to niełatwa praca ,jednoczenia", które często wymaga pełnej uwagi osoby zdolnej do empatii.

Towarzyszący (formator) musi umieć oscylować pomiędzy pełnią i brakiem, pomiędzy obecnością i nieobecnością. Nie jest dobrze, jeśli formator nie jest wystarczająco „inny”, tak aby przeciwstawić się i przyjąć rolę granicy, która jest jednocześnie wyzwaniem i zaproszeniem do transcendencji. Wychowanie polega na zaoferowaniu empatii we wchodzeniu w takie relacje bardziej lub mniej niedojrzałe, naznaczone „frustracją optymalną", która wspiera transformację ku pełnej dojrzałości'. W świetle złożoności świata relacji i ich zna-

8 Por. F. Imoda, Sviluppo umano. Psicologia e mistero, Bologna 2005, s. 288, 291.

9 Por. F. Imoda, Sviluppo umano, dz. cyt., s. 281. Autor odnosi się do trzech rodzajów przeniesienia opisanych przez Kohuta i należących do procesu rozwoju, czyli: poczucia wielkości, idealizacji oraz naśladowania. W tym wypadku podkreśla etapy 
czenia w stawaniu się osobą dojrzałą trzeba podkreślić, jak bardzo ludzka mediacja pozostaje kluczowym kanałem wzrostu. Nie chodzi tu o relację jakąkolwiek, ale taką, która będzie umiała wejść na ścieżkę rozwoju, oferując się jako pytanie i odpowiedź, jako wyzwanie i wsparcie, jako przeszkoda i obietnica. To wprowadza nas w konkret relacji, która, prezentując zarówno aspekty obecności, jak i nieobecności, spełnia swoją rolę promowania dojrzałości osoby, biorąc pod uwagę trzy dynamiki natury i ducha, pojawiające się $w$ formacji, tj.: trening - nauka - transformacja ${ }^{10}$.

Formator obecny (empatia, zintegrowana interakcja, otwartość na Trzeciego)

Na początku mamy do czynienia z bardzo ważnym pojęcie, którym jest empatia. Uważa się ją za nieodzowną dla ludzkiego życia. Jako rozszerzenie tematu skupię się na najbardziej namacalnym doświadczeniu relacji między formatorem a formowanym, potem wszystko będzie umieszczone w kontekście relacji z Bogiem, który sprawia, że wszystkie inne relacje, szczególnie te formacyjne, stają się głębsze i bardziej intymne.

dojrzewania relacji formacyjnej, która zanim osiągnie swoją pełnię, czyli relacji w której w pełni są respektowane odrębności osobowe, przechodzi przez etapy naznaczone potrójnym przeniesieniem (poczucie wielkości, idealizacja, naśladowanie). Świadomość tych procesów może umożliwić działanie ku ich urealnieniu i w końcu, pozostawieniu, aby nie warunkowały działania osób dorosłych.

10 Trening jest definiowany jako utrzymanie określonego porządku, aby dotrzeć do wyznaczonego celu poprzez porzucenie systemów motywacyjnych polegających na przypodobaniu i identyfikacji, a oparciu się na internalizacji ideałów. Nauka ma służyć poznaniu odpowiedzi na pytanie „jak?” Zrozumienie ma prowadzić do odkrycia znaczenia danej drogi, czy decyzji obranej. Transformacja natomiast, jako owoc przebytej formacji, niesie głęboką zmianę osiągniętą poprzez głęboką i permanentną znajomość siebie i zdolność do osobistej ofiary z życia. Por. J. Ridick, J. Dyrud, Training, insegnamento, trasformazione nella formazione religiosa, w: Antropologia interdisciplinare e formazione, red. F. Imoda, Bologna 1997, s. 253-269. 


\section{Empatia}

Empatia jest jedną z dyspozycji, które sprawiają, że relacje interpersonalne mogą być autentyczne i prowadzić do osobistego rozwoju. Pozwala ona czuć się akceptowanym i zrozumianym oraz umożliwia wyrażenie siebie. Dużo się o niej mówi, ale być może jeszcze nie wystarczająco. To nie jest strategia ani wyekstraktowany środek medycyny niekonwencjonalnej, ale umiejętność, która opiera się na pragnieniu autentyczności i prawdy, które każda osoba konsekrowana winna posiadać.

Według Schafera empatia ,jest udziałem” i zrozumieniem w sposób poznawczy i emocjonalny stanu psychicznego innej osoby, która jest uznana jako osoba kompletna i postawiona w danym momencie jej życia ${ }^{11}$. Richard S. Lazarus nie pojmuje empatii jako emocji, ale jako „zdolność emocjonalną” i mówi, że „empatia nie jest uczuciem, ale raczej zdolnością lub dyspozycją do dzielenia emocji innych..."12. Mead i Piaget umieszczają jednak empatię w obszarze zdolności kognitywnych osoby. Jest to raczej „wejście w rolę innej osoby, aby dopiero ocenić emocjonalnie jakie znaczenie ma dana sytuacja dla niej" ${ }^{\prime 3}$. Empatii - jak uważa Kohut - nie należy mylić z sympatią, ani współczuciem. Empatia jest natomiast „koniecznym warunkiem dla zdolności odczuwania współczucia"14.

Franco Imoda definiuje empatię jako „zdolność do udziału w doświadczeniu drugiej osoby, poprzez przeżycie go w sobie." Empatia ma swoje odniesienie w sytuacji obecności czyli „czasu bezpieczeństwa”, odpowiedzi, równowagi osiągniętej przez człowieka ${ }^{15}$. To jest czas, który towarzyszy odpowiedzi danej lub znalezionej; jest sytuacją odpowiadającą sukcesowi w pokonywaniu napięcia lub znajdowaniu

11 R. Schafer, Generative empathy in the treatment situation, w: Psychoanalytic Quarterly, 28, s. 342; seguendo: T.H. Ogden, La identificazione proiettiva e la tecnica psicoterapeutica, Roma 1994, s. 70.

12 Tamże, p. 287.

13 U. Galimberti, Dizionario di psicologia, s. 333.

14 H. Kohut, Introspezione ed empatia. Raccolta dei scritti (1959-1981), red. A. Carusi, Torino 2003, s. 175.

15 Por. F. Imoda, Sviluppo umano, dz. cyt., s. 256. 
rozwiązania problemu. To czas obecności wobec drugiego i obecności drugiego wobec mnie"16. Każdy z tych trzech elementów może oferować prawie niekończące się możliwości wspierania rozwoju, jak również może prowokować szereg przeszkód, prowadzących ostatecznie do zablokowania rozwoju ${ }^{17}$. Tak więc empatia w wychowaniu i rozwoju musi zostać skonfrontowana $\mathrm{z}$ konfliktem wobec nowych pytań, prowokacji i uznania.

Empatia w relacji międzyosobowej pozwala jednocześnie zaistnieć doświadczeniu bliskości i wolności innych osób. Ma wielką wartość wychowawczą/formacyjną, ponieważ wymaga reorganizacji własnego systemu potrzeb, wartości i pragnień. Jest to postawa, która formuje relacje i pozwala rozpoznać w drugim obraz i podobieństwo Boga, rozwijając poczucie podstawowego przykazania miłości bliźniego jak siebie samego. Empatyczne rozumienie polega na równowadze pomiędzy zrozumieniem drugiego bez pochopnych, osobistych i egoistycznych interpretacji i zaangażowania emocjonalnego, bez popadania w identyfikacje $e^{18}$.

Relacje oparte na empatii nie tylko pozwalają czuć się zaakceptowanymi w swej godności i wartości osoby, ale otwierają na podzielenie się stanami serca. Dla prawdziwej transformacji formator musi nawiązać z kandydatem osobistą relację, która wykracza poza spotkania przy stole, aby stać się dla każdego prowadzonego bratem umysłu, serca i duszy. Prawda, empatia i miłość wymagająca powinny stanowić składniki rzeczywistej relacji.

\section{Zintegrowana interakcja}

Byłoby właściwe, aby relacja pomiędzy formatorem i formowanym była jednocześnie na poziomie społecznym, duchowym i wychowawczym. Dlatego istotnym jest ofiarowanie wystarczająco dużo czasu,

\footnotetext{
16 Tamże, s. 168 ; por. s. 167-178.

17 Por. tamże, s. 257.

18 Por. S. Gorla, La relazione: crea comunità religiose nuove di amicizia e fraternità, w: V. Mariani, La relazione: incontro quotidiano con Dio e con l'uomo, Bologna 2008, s. $44-45$.
} 
aby umożliwić częste i pogłębione spotkania, pozwalające by młodzi mogli czerpać od swojego nauczyciela pewne wzory. Wychowawca powinien być zdolny do poufnej relacji, dzieląc się swymi myślami, reakcjami, opiniami, aby osoba prowadzona mogła uświadomić sobie, w jaki sposób formator integruje sferę duchową, intelektualną, ludzką i osobistą. Powinien być w stanie modlić się, śmiać, martwić i zachować pokój, kiedy prowadzony wyraźnie ujawnia część siebie. Formowany musi zobaczyć, że jak jego wychowawca ma głęboką wewnętrzną witalność, tak również on może nią kierować samodzielnie lub $\mathrm{z}$ pomocą innych zaufanych osób w seminarium, szczególnie $\mathrm{z}$ pomocą Boga ${ }^{19}$.

Aspektem zapomnianym lub niedocenianym na etapie formacji jest wspólna praca. Jest ona wartością, która przynosi wiele potencjału wychowawczego. Wykonywać rzeczy razem, uczyć się razem, jest warunkiem koniecznym, aby formacja była zintegrowana. To wspólne pracowanie powinno jednocześnie mieć znaczenie, cel, smak podejmowanego wysiłku. Nie wystarczy zrobić. Potrzeba, aby ta praca miała sens; aby można było uchwycić jej znaczenie jako coś pięknego i dobrego ${ }^{20}$. Prowadzi to nie tylko do wspólnej pracy, ale promuje wspólne myślenie i czucie. Wydaje się, że model kształcenia dzisiaj staje się bardzo wyrafinowany, abstrakcyjny, teoretyczny. Klerycy spędzają dużo czasu na studiowaniu książek i rozpraw teologicznych, ale często brakuje im podstawowych zdolności, które przynoszą ze sobą poczucie umiejętności i, jak mówi Erikson, kompetencji ${ }^{21}$. Nie są to tylko umiejętności techniczne, które można zdobyć w sposób stosunkowo łatwy. Chodzi bardziej o poczucie przynależności i odpowiedzialności za plan Boga. Pracując i spełniając proste czynności, człowiek ma okazję do łączenia życia ziemskiego z życiem duchowym.

\footnotetext{
19 Por. J. Ridick, J. Dyrud, Training, insegnamento, trasformazione nella formazione religiosa, in: Antropologia interdisciplinare e formazione, red. F. Imoda, Bologna 1997, s. 274-275.

20 Por. E. Meloni, Accompagnare la formazione, Bologna 2005, s. 43-44.

21 Por. C.S. Hall, G. Lindzey, J.B. Campbell, Theories of personality, New York 1997, s. 197.
} 
Zwykliśmy mówić, że przeżywanie wartości duchowych wpływa na sposób przeżywania wartości naturalnych, takich jak: przyjaźń i szczerość. Podejmując jednak razem trud pracy, pogłębiamy wartości duchowe. $\mathrm{W}$ jednym $\mathrm{z}$ wywiadów $\mathrm{z}$ mnichem kamedulskim można przeczytać: „Celem pracy jest osiągnięcie pełnego zjednoczenia osoby, aby mogła być bardziej prawdziwa i jasna w naszym utożsamieniu się z dzieckiem Ojca, który nas kocha, z bratem i całym stworzeniem. To jest głęboka potrzeba zapisana w zbawczej tajemnicy Wcielenia. Z takiej drogi nie można wykluczyć, wymiaru pracy, jeśli chcesz uniknąć niebezpiecznych zachowań „spirytualizujących” lub „materialistycznych”, a w efekcie uniknąć formowania mnichów, w obu przypadkach, bezcielesnych. Jak mówi stare przysłowie: „Praca uszlachetnia człowieka” przez integrowanie z ludzkością i całym stworzeniem i służy pełnemu zjednoczeniu, czyniąc z osoby pełną osobę i mnicha zrealizowanego w dążeniu do pełnego zjednoczenie ze sobą"22.

Można przytoczyć wiele cytatów, które potwierdzają ważną rolę pracy w życiu człowieka. Jako najważniejszy dokument jawi się encyklika Jana Pawła II Laborem exercens. Nasza myśl idzie raczej w kierunku wartości formacyjnej wspólnej pracy, gdzie formatorzy i formowani spotykają się, wyrażając siebie i rozwijając świat swych wartości ${ }^{23}$. Właśnie wyrażanie siebie, które pociąga za sobą zaangażowanie fizyczne odgrywa ważną rolę w procesie wzrostu. Formować się oznacza także nabywać umiejętności i kompetencje, które następnie poszerzają horyzonty osoby. Czynią ją bardziej odpowiedzialną i praktyczną w procesie uczestnictwa w „stwarzaniu świata”. Oprócz łączenia wspólnoty, praca ma także osobiste walory, to znaczy, posiadanie przestrzeni do sublimacji naturalnych energii. Praca manualna stwarza przestrzeń nauki, dzielenia wspólnych doświadczeń,

\footnotetext{
22 A. Margarino, Lavoro e vita monastica, Intervista ad Arrigo Anzani, monaco camaldolese, http://www.fabbricafilosofica.it /MA/08/02.html [dostęp: 20.06.2011 r.). 23 Jan Paweł II w encyklice o pracy ludzkiej opisuje wartość pracy w rodzinie. Wyróżnia dwa aspekty: utrzymanie rodziny oraz wychowanie do przyszłej aktywności profesjonalnej. Por. Jan Paweł II, Laborem Exercens, Rzym 1981, nr 10.
} 
pokonywania różnych bloków intrapsychicznych. Oczywiście, praca może stać się także przyczyną frustracji, zwłaszcza, gdy nie przynosi widocznych rezultatów lub ujawnia osobiste braki. Osoba z niską samooceną może bać się pracy, która pokazuje deficyty na poziomie praktycznym, lub może wykorzystywać pracę jako środek do zabezpieczenia sobie pozycji w grupie. Oczywiście ta różnorodność aspektów pomaga poznać siebie. Jeżeli praca służy rozwojowi i jest prawidłowo prowadzona przez formatora znajduje się w zakresie formacyjnej obecności.

Inny aspekt pracy dotyczy możliwości promowania odpowiedzialności za wspólne dobro i dyspozycję, aby służyć innym. Posiada również wartość integrującą. W pracy bowiem sfery poznawcza (myśli), afektywna (emocji) i konatywna (decyzji) spotykają się w bardzo konkretny sposób. Może to być praktykowane jako środek kształtowania daru z siebie dla drugiego i brania odpowiedzialności w życiu osobistym.

Nie jest moim zamiarem przecenianie roli pracy w życiu konsekrowanym. Brak równowagi może prowadzić do degradacji człowieka i jego powołania. Jeśli dochodzi do wyzysku młodego człowieka, szczególnie we wspólnotach starzejących się, zwłaszcza w świecie zachodnim, sama praca staje się utrudnieniem dla wzrostu i zmarginalizowaniem osoby jedynie do sfery materialnej. Takie fakty nie są niestety rzadkością.

Obecność formatora objawia się również w postawie słuchania, wrażliwości na przyjęcie młodego człowieka. Dzieje się tak nie tylko w kierownictwie duchowym czy rozmowach. Ta przyjazna postawa powinna być obecna w każdym momencie życia wspólnoty. Kiedy wychowawca ma przyjazną postawę, słucha i interpretuje opowiadane życie, doceniając jego mocne aspekty. Chodzi o zauważenie obecności ${ }^{24}$ :

- pozytywnych postaw i umiejętności,

- emocji i potrzeb spontanicznie otwartych ku dobremu życiu

24 A. Facchinetti, Ascoltare e interpretare in ottica cristiana, "Tre dimensioni” 2007, nr 4, s. 52. 
- wartości i ideałów dojrzałych,

- wartości i ideałów chrześcijańskich.

Oznacza to konkretne poszukiwanie w codzienności znaków:

- uczciwości, lojalności, hojności, cierpliwości, wytrwałości,

- równowagi, niezależności, dystansu,

- otwartości, dyspozycyjności, zaufania,

- ofiarności, zaangażowania,

- modlitwy, częstego przystępowania do sakramentów.

\section{Otwarcie na Trzeciego}

Kolejnym sposobem wyrażania obecności formatora przy formowanym, który sprawia, że relacja między nimi jeszcze się pogłębia, jest otwarcie na Boga. Międzyludzka relacja potrzebuje fundamentu, nie znajduje bowiem wewnątrz samej siebie, ostatecznej racji bytu. Tylko obecność „Trzeciego” gwarantuje wierność i pewność ludzkiej miłości, konsoliduje ją i jej broni. Daje poczucie bycia kochanym od zawsze i na zawsze. W końcu wreszcie odniesienie do Boga, nadaje relacji granice. Możemy w ten sposób ocenić, jak daleko się posunąć, gdy bezwarunkowa akceptacja prawdopodobnie będzie bezproduktywna, gdy konieczne jest zaznaczenie pewnych warunków, a nawet kiedy zachodzi obowiązek postawy wymagającej lub zlecającej. Wtedy, jak mówi Cencini, relacja międzyludzka staje się drogą do wiary. Ujawnia wrodzoną ludzką skłonność do relacji, ale pokazuje również ludzką potrzebę nadania bożej podstawy tej tendencji. Należy wskazać jej formę, wiążące kryterium, aby zachować spotkanie i zapewnić mu stabilność ${ }^{25}$.

Poszukiwanie Boga powinno być główną motywacją, która sprawia, że mężczyźni stają się zdolni do budowania relacji, w których szczególne miejsce ma Bóg, a nie emocjonalne potrzeby. Jak mówił kard. Hume: „Musisz wypełnić swój umysł i swoje serce ogromnym pragnieniem Boga i spraw Bożych, nie zawsze będę mógł to uczynić na najwyższym poziomie, ale powinno to być coś do czego zawsze

25 Por. A. Cencini, Dalla relazione alla condivisione, Bologna 2002, s. 50, 53. 
dążę"26. Ważne jest, aby przekazać to formowanemu. Obecność Łaski, doświadczanej w walce duchowej, rozpoznana i przedyskutowana, jest najlepszym narzędziem, które może przynieść odwagę pójścia drogą krzyża w kierunku integracji, uporządkowania i ukierunkowania własnych potrzeb w procesie odkupienia i transformacji. $\mathrm{Na}$ tym polega integracja psychologii i teologii, natury i łaski ${ }^{27}$.

Przed przystąpieniem do opracowywania tego tematu zwróciłem się do moich współbraci kleryków z pytaniem: jakie cechy powinien według nich posiadać formator na dziś. Rezultaty nie są całkowicie zaskakujące, choć pozostają w pewnym względzie ciekawe w interpretacji. Poprosiłem o to najpierw kleryków pierwszego roku seminarium, a potem tych z roku szóstego. Młodsi na pierwszym miejscu umieścili autentyczną i głęboką relację z Bogiem. Staje się ona punktem wyjścia (modlitwa, świadectwo). Potem są: umiejętność słuchania, empatia, otwartość na dialog, skromność, szczerość, aktywna obecność w życiu seminarzystów, cierpliwość, radość, itd. Ci starsi natomiast dali odpowiedzi w większości nieco inne. Oni położyli nacisk przeważnie na sferę ludzką formatora. Wyróżnili następujące cechy: ojcowski, normalny, zrównoważony, ludzki, szczery, autentyczny, empatyczny, a potem podeszli do takich, jak: uduchowiony, człowiek modlitwy itp. Różnica ta okazuje się ciekawa. Możliwa interpretacja mogłaby pójść w kierunku ideałów, które prezentują klerycy. Jakie priorytety mają? Ci po formacji początkowej kładą nacisk i kierują uwagą bardziej na fundament, na człowieczeństwo formatora, natomiast młodzi szukają bardziej wzorca modlitwy. Jeśli chodzi o punkt wyjścia, to słuszny wydaje się ten zaprezentowany przez starszych, ale dojrzałość ludzka powinna być jeszcze ubogacona wartościami transcendentalnymi, religijnymi i w taki sposób kształtować człowieka dojrzałego z punktu widzenia duchowego.

\footnotetext{
26 B. Hume, Operai del vangelo. Diaconi, preti, vescovi, laici, Milano 1992, s. 30.

27 Por. J. Ridick, J. Dyrud, Training, insegnamento, trasformazione nella formazione religiosa, in: Antropologia interdisciplinare e formazione, red: F. Imoda, Bologna 1997, s. 276.
} 
Formator nieobecny (formacja to nie przyjaźń, konfrontacja, samotność)

Jeśli sytuacja zbyt wielu niezaspokojonych potrzeb nie sprzyja rozwojowi, to nie sprzyjają mu również realia zbyt dużej satysfakcji. Całkowita satysfakcja potrzeb i pragnień uniemożliwiłaby szukanie odpowiedzi na wewnętrzne pytania i w konsekwencji wzrost oraz dojrzewanie osoby.

Dlatego chwile nieobecności w życiu człowieka, zwłaszcza w czasie formacji, ale także w całym życiu, stają się okazją, by obudzić w nim chęć przejścia na wyższy horyzont. Procesowi temu towarzyszy lęk, ponieważ pragnienie pojawia się w sytuacji braku, zagubionej równowagi, kiedy człowiek nie czuje się jak u siebie i ma wrażenie walki, ponieważ przeżywa opór przed poszerzaniem własnego horyzontu ${ }^{28}$. Postaram się teraz podkreślić znaczenie odpowiedniej nieobecności formatora podczas procesu formacyjnego. Relacja wychowawcza nie jest w istocie relacją przyjaźni i musi mieć przestrzeń dla konfrontacji i samotności.

Relacja formator-formowany nie jest relacja przyjaźni

Czasami w formacji spotyka się relację formator - seminarzysta/juniorystka, która spełnia bardziej kryteria przyjaźni niż kierownictwa. W grupie może wyłonić się jeszcze jedna kwestia, a mianowicie preferencje, które niosą ze sobą zniszczenie powołania osoby wyróżnionej i taka relacja jest wprost w opozycji do formacji. Konieczne jest zatem jednoznaczne stwierdzenie, że relacja formacyjna nie jest relacją przyjaźni. Ona może ułatwić zaufanie w pierwszych chwilach znajomości, ale utrudnia pogłębienie jej. Manenti podchodzi do tego problemu w odniesieniu do roli formatora w kontekście relacji pomocniczej. Ja stosuję to podejście szerzej $\mathrm{w}$ odniesieniu do relacji formacyjnej w ogóle: „Im bardziej człowiek odkrywa się w swej intymności, tym bardziej wymaga ochrony w owej intymności. Kierownik wchodzi w życie drugiej osoby tylko za jej zgodą i do tego momentu, do którego ta zainteresowana osoba ponawia to pozwolenie. (...) Wydaje się,

28 Por. F. Imoda, Sviluppo umano, s. 173. 
że przyjaźń usuwa to ograniczenie, ponieważ może nieświadomie wystąpić oczekiwanie relacji egzystencjalnej i trwałej, podczas gdy relacja pomocnicza jest tymczasowa"29.

Innym aspektem, który podkreśla różnicę między przyjaźnią i relacją pomocową jest wzajemność, która nie występuje w formacji. Tutaj formator ma kontrolę nad sytuacją i stawia zasady: nie podejmuje jakichkolwiek pytań, ale tylko te, które są źródłem wzrostu. Ponad relację interesuje go wzrost danej osoby i nie może ulec milczącym kompromisom, aby uratować relację. Przyjaźń ta może zatem stać się przeszkodą, ograniczając spotkanie do intymnej rozmowy, która ucieka się do satysfakcji wtórnych, unikając podejmowania tematów trudnych. Kiedy masz emocjonalne więzi z ludźmi jest bardzo trudne, aby im pomóc w duchu obiektywnego dystansu, który jest konieczny ${ }^{30}$.

\section{Konfrontacja}

Gdy formator ma postawę konfrontacji i towarzyszenia jest bardziej uważny, aby zidentyfikować punkty słabe i problemy formowanego. Chodzi o uchwycenie wrażliwych i obronnych aspektów, poznanych w sytuacjach „obecności” i zastanowienie się, czy to jest kwestia: ograniczeń lub psychologicznej kruchości o charakterze kognitywnym, afektywnym lub dotyczącej woli:

- bloków w rozwoju,

- niedojrzałości na poziomie ideałów chrześcijańskich,

- braku w cnotach czysto ludzkich,

- trudności duchowych/moralnych,

- stylu lub logiki życia prezentującej dysonans z wartościami głoszonymi.

Momenty konfrontacji, chociaż bolesne, pomagają osobie poznać się. Jeśli formator umie znaleźć równowagę pomiędzy „obecnością” i „nieobecnością”, to kleryk będzie mógł łatwiej utrzymać relację zaufania $\mathrm{z}$ formatorem i jednocześnie wyciągnąć praktyczne informacje

29 A. Manenti, Vivere gli ideali, dz. cyt., s. 225.

30 Por. tamże, s. 225-226. 
dla samopoznania się, a to prowadzi do samoakceptacji. W rzeczywistości, to jest cel pomocy formacyjnej.

Konfrontowanie wymaga od formatora, że to on pierwszy będzie pogodzony ze swoimi wewnętrznymi trudnościami. Tak więc, mając przepracowane doświadczenie „neurotyczne”, będzie w stanie lepiej zrozumieć osobę, które stoi przed nim i dać porady, które poprowadzą do wzrostu, a nie będą służyły zaspokojeniu potrzeb emocjonalnych formatora.

\section{Samotność}

Pozostając na poziomie relacji formacyjnej, idąc za Imodą, możemy stwierdzić, że taka relacja powinna stawać się bezużyteczną sam przez się, będąc jedynie mediatorem rzeczywistości bardziej obiektywnej i transcendentnej, przed którą formator będzie umiał się usunąć na bok i pomniejszyć. Znajdujemy taki model również w „strategii pedagogicznej" samego Jezusa, który powiedział do swoich uczniów: „Lepsze jest dla was moje odejście” $(J 16,7)^{31}$.

Samotność nie jest sprzeczna z komunikowaniem. Takie znaczenie miałaby raczej „izolacja”. Samotność, jednak może współistnieć, a nawet musi współistnieć $z$ komunikacją na głębszym poziomie ${ }^{32}$. Samotność ma kilka znaczeń: dar z życia i wybór życia. Jest samotność, która jest częścią egzystencjalnego doświadczenia każdego człowieka, ponieważ wynika z niezrozumienia, odrzucenia, emocjonalnej pustki, itp., ale jest również taka, która wynika $z$ dobrowolnego i indywidualnego wyboru, w szczególności wtedy, kiedy np. relacja zaczyna być zbyt uciążliwa. Są to cenne chwile dla wzrostu w miłości Bożej, szczególnie dla doświadczenia miłości, która pochodzi od Niego. Tak długo, jak nie jesteśmy sami, nigdy nie nauczymy się cieszyć Jego przyjaźnią i nie zdobędziemy doświadczenia, że możemy sami stać na swych nogach, ufając tylko Jemu ${ }^{33}$. Nouwen nazywa samot-

\footnotetext{
${ }^{31}$ Por. F. Imoda, Sviluppo umano, dz. cyt., s. 292.

${ }^{32}$ Por. tamże, s. 37.

33 Por. A. Cencini, Amerai il Signore Dio tuo. Psicologia dell'incontro con Dio, Bologna 2009, s. 113.
} 
ność „piecem, w którym zachodzi transformacja” i mówi, że nie jest to miejsce terapii, ale „miejsce nawrócenia, miejsce, gdzie stary człowiek umiera i rodzi się nowy" ${ }^{34}$.

„Samotność nie jest prywatna, w odróżnieniu od czasu spędzonego razem, nie jest nawet czasem, aby odświeżyć nasze zmęczone umysły. Samotność to coś innego niż czas poza wspólnotą; samotność jest obszarem, na którym wspólnota wzrasta. Kiedy modlimy się sami, studiujemy, czytamy, piszemy lub po prostu spędzamy spokojnie godzinę z dala od miejsc, w których bezpośrednio lub pośrednio współdziałamy ze sobą, wchodzimy w głęboką wspólnotę ze sobą. Błędem jest myśleć, że zbliżamy się do siebie tylko wtedy, gdy rozmawiamy, gramy lub pracujemy razem. Oczywiście, ważny wzrost zachodzi podczas tych ludzkich interakcji, ale te interakcje czerpią owoc z samotności, bo samotność pogłębia naszą wzajemną intymność. W samotności odkrywamy się wzajemnie i poznajemy w taki sposób, w jakim fizyczna obecność może to utrudniać, jeśli nie uniemożliwiać"35.

W samotności człowiek dochodzi do konfrontacji z samym sobą. Nie mając nikogo obok, jest bardziej skłonny do rozeznawania własnych motywacji, wybierając zawsze w kierunku „dobra samego w sobie”, a nie „dobra dla mnie”. Samotność pozwala rozpoznać osobiste motywacje. Oczywiście, w tym procesie wartość zajmuje pozycję centralną. Będąc sam, człowiek przechodzi z bezpośrednich relacji z ludźmi do relacji z Bogiem, która kształtuje się za pośrednictwem tych ludzkich.

\section{Zakończenie}

Możemy zatem powiedzieć, że formator czy formatorka na dziś jest osobą, która zna i umie przeżywać swoje człowieczeństwo i rozpoznaje procesy własnego serca, aby lepiej zrozumieć, w empatycznej relacji, tego, kto jest w drodze do własnego serca, gdzie spotka Boga żywego i dialogującego. Nie oczekujmy formatorów idealnych, ale

\footnotetext{
34 H.J.M. Nouwen, Il primato dell'amore, Brescia 2001, s. 122.

35 Tamże, s. 123-124.
} 
prawdziwych, mądrych, mających głęboką wiedzę o ludzkim sercu. Aby mieć taką wiedzę, odnosząc się do dokumentu Kongregacji Wychowania Katolickiego, musimy rozwijać wrodzone talenty, jakie otrzymaliśmy od Pana i ubogacać je umiejętnościami nabytymi.

\section{Streszczenie}

Formator to osoba, która jest zdolna służyć drugiemu tak, że razem postępują w procesie stawania się coraz bardziej ludzcy. Obydwoje bowiem są dziećmi dzisiejszego świata i dziedziczą z niego zarówno silne, jak i słabe cechy. Formator ma być wystarczająco dobry, co oznacza wrażliwość potrzebną do odpowiadania na potrzeby formowanego poprzez swoją obecność, ale również umiejętność dawania potrzebnej przestrzeni do doświadczania tych potrzeb, jednak w wymiarze, który nie będzie oznaczał straty. Widoczna jest w tym rola dynamiki obecności i nieobecności poprzez doświadczenie satysfakcji i frustracji. Te elementy są obecne w relacji formacyjnej po to, by kandydat mógł poczuć się bezpiecznie i mógł aktywnie szukać odpowiedzi na pytania drzemiące $\mathrm{w}$ nim. Ten który przyjmuje rolę towarzyszenia, powinien zdobyć umiejętność balansowania pomiędzy pełnią (obecność) i brakiem (nieobecność). Słabością formatora jest bycie niewystarczająco innym, co pozwala na przyjęcie roli granicy, która staje się wyzwaniem i zaproszeniem do transcendencji.

\section{Summary}

The formator for today is one who is capable of serving the other, so that all together become better human beings. That both the candidates and the formators are children of today's society and that both inherit not only the strong points but also the weak points of all that goes on around them. The formator has to be sufficiently good, that means, he/she has to be ready and capable of responding to the needs of the one in formation with a presence, but also capable of allowing a sufficient space to experience need, and that does not transform itself into a situation of deprivation. It is precisely at this point that once more the game of presence and absence comes to the fore, in the sense of satisfaction and frustration. These elements should be present in the formative relationship in order that the candidate has the possibility to feel secure, and at the same time encouraged to seek answers to the questions that he/she carries within themselves. 
The one who accompanies has to know how to fluctuate between fullness (presence) and privation (absence) in his/her way of accompaniment. It is not good if the formator does not arrive to be sufficiently other in a way of self-opposition and to assume the role of a limit, that is at the same time a challenge to overcome and an invitation to transcendence.

Słowa kluczowe: formacja, integracja osobowościowa, relacja formacyjna, towarzyszenie w powołaniu, wartości chrześcijańskie

Key words: formation, personality integration, formative relationship, vocational accompaniment, Christian values

\section{Bibliografia}

Cencini A., Amerai il signore tuo Dio. Psicologia dell'incontro con Dio, Bologna 2009.

Cencini A., Dalla relazione alla condivisione, Bologna 2002.

Facchinetti A., Ascoltare e interpretare in ottica cristiana, „Tre dimensioni” 2007, nr 4, s. 51-64.

Galimberti U., Dizionario di psicologia, Torino 2006.

Goleman D., Inteligenza emotiva, Milano 1999.

Gorla S., La relazione: crea comunità religiose nuove di amicizia e fraternità, w: V. Mariani, La relazione: incontro quotidiano con Dio e con l'uomo, Bologna 2008.

Hall C.S., Lindzey G., Campbell J.B., Theories of personality, New York 1997. Hume B., Operai del vangelo. Diaconi, preti, vescovi, laici, Milano 1992.

Jan Paweł II, Laborem Exercens, Rzym 1981.

Kohut H., Introspezione ed empatia. Raccolta dei scritti (1959-1981), red. A. Carusi, Torino 2003.

Kongregacja Wychowania Katolickiego, Direttive sulla preparazione degli educatori nei seminari, Rzym 1993.

Meloni E., Accompagnare la formazione, Bologna 2005.

Mickiewicz F., Nowy Komentarz Biblijny. Nowy Testament. Ewangelia wg. św. Łukasza, III/2, Częstochowa 2012.

Nouwen H.J.M., Il guaritore ferito, Brescia 2007.

Nouwen H.J.M., Il primato dell'amore, Brescia 2001.

Ogden T.H., La identificazione proiettiva e la tecnica psicoterapeutica, Roma 1994. 
Ridick J., Dyrud J., Training, insegnamento, trasformazione nella formazione religiosa, w: Antropologia interdisciplinare e formazione, red. F. Imoda, Bologna 1997, s. 245-283.

Rulla L., Antropologia della vocazione cristiana I, Bologna 2006.

Sobór Watykański II, Optatam totius. Dekret o formacji kapłańskiej, Rzym 1965.

\section{Biogram}

Ks. Artur Stępień SAC (ur. 1978 r.) - katolicki duchowny, pallotyn, absolwent Instytutu Psychologii na Papieskim Uniwersytecie Gregoriańskim oraz studiów doktoranckich w Centrum Teologii Apostolstwa „Pallottianum” w Otarzewie, wykładowca w Szkole Formatorów na Ignatianum w Krakowie, prowadzi kolokwia wzrostu dla osób konsekrowanych i świeckich. Święcenia kapłańskie przyjął w 2004 r. po czym rozpoczął pracę duszpasterską na Podolu, pełniąc funkcję odpowiedzialnego za postulat dla kandydatów z Ukrainy. Po trzech latach został skierowany na studia specjalistyczne do Rzymu, a po ich ukończeniu w 2012 r. podjął pracę formacyjną w pallotyńskim seminarium. W roku 2013 został mianowany członkiem Generalnego Sekretariatu ds. Formacji przy Zarządzie Generalnym Księży Pallotynów. 